\title{
КРИМІНАЛЬНИЙ РАДИКАЛІЗМ: ОСНОВНІ КРИМІНОЛОГІЧНІ ТИПИ
}

\author{
МАСЛОВА Наталія Григорівна - кандидат юридичних наук, докторант \\ (Харківський національний університет внутрішніх справ) \\ ORCID:0000-0002-9009-1254 \\ DOI:10.32782/NP.2020.1.16 \\ УДК 343.85
}

Стаття присвячена типологї̈ кримінального радикалізму. За спрямованістю агресї виділено екзоагресивний, ендоагресивний та змішаний радикалізм. За бормою прояву - вербальний та синтетичний. В залежності від ідейною основи запропоновано розрізняти політичний, релігійний, ксенобобний, субкультурний та змішаний типи кримінального радикалізму. Політичний кримінальний радикалізм виявляеться багатоплановим, у зв'язку з чим може бути репрезентований такими підтипами за критерієм ідейного базису: правоідеологічний (архаїчний, начіоналістичний), лівоідеологічний, анархістсъкий, антиглобалістсъкий, «зелений», антикримінальний радикалізм. В залежності ж від спрямованості діяльності виділяються такі підтипи політичного кримінального радикалізму: радикалізм-бунт (антидержавний радикалізм) $i$ радикалізмтерор (державний радикалізм: терор, державний тероризм, злочини агресії).

Ксенобобний радикалізм має такі підтипи: антисемітизм, расизм, та мігрантофбобний радикалізм. Серед підтипів субкультурного радикалізм виділено такі: 1) молодіжно-субкультурний (радикалізм футтбольних фбанатів, рух скінхедів тощо); 2) кримінально-субкультурний. Останній, в свою чергу має ще два підтипи: а) внутрішнъо-субкультурний, який проявляється всередині угрупувань засуджених та пов'язаних зі спробами змінити тюремний устрій, окремі інститути, норми, ієрархічну структуру, передбачену відповідною субкультурою; б) зо- внішньо-субкультурний, що виражає протистояння з іншими контркультурами, нормосистемами, порядками.

За функиіями в політичному процесу виділено такі типи кримінального радикалізму: «револючійний рух», політичні репресї, політичний терор, кримінальний сепаратизм, тероризм (поліфбункиіональний політикокримінальний феномен), вандалізм. Запропоновані типи кримінального радикалізму не є вичерпними та можуть доповнюватись, набувати інтегративних рис в залежності від ситуацій, конкретного суб'єктивного змісту злочинних дій, використанням їх ебектів суб'єктами політики тощо.

Ключові слова: кримінальний радикалізм, типологія, ідеологія, спрямованість, прояв, бункиія.

Актуальність теми

Кримінальний радикалізм, будучи багатовимірним феноменом, характеризується вельми строкатою палітрою своїх проявів. Останні різняться за характером, спрямованістю, методами, ідеологічним обрамленням тощо. Звісна річ, навряд чи можливо перерахувати всі можливі прояви кримінального радикалізму, хоча 6 на тій підставі, що останній в межах кримінологічної доктрини і практики відноситься до різновидів злочинності, а, відтак, має властивість мінливості, виявляє значний соціально конструктивістський сегмент своєї природи. Водночас, принципова пізнавальна цілісність цього феномену, яка складає необхід- 
ну гносеологічну передумову для такого ж цілісного, системного підходу у справі протидії його відтворенню, диктує необхідність у їі структуруванні. Без структурування як способу ускладнення (через деталізацію) знання про радикалізм неможливо забезпечити подальший пізнавальний рух та, відповідно, ефективну кримінально-превентивну практику. Серед методів структурування знання про процеси і явища в науці широко поширеним є типологія.

Теоретико-прикладні проблеми протидії кримінальному радикалізму досліджувались у працях О. М. Бандурки, Ю. Б. Данильченка, В. О. Глушкова, С. Ф. Денисова, В. П. Емельянова, А. Ф. Зелінського, Н. А. Зелінської, О. М. Костенка, О. М. Литвинова, Г. В. Маляр, Ю. В. Орлова Е. Л. Стрельцова та інших вчених.Однак кримінологічна типологія й до сьогодні здійснена не була.

Мета статті - виділити, описати та пояснити основні кримінологічні типи кримінального радикалізму.

\section{Виклад основного матеріалу}

Здійснені нами аналіз та узагальнення наявних кримінологічних, соціологічних, політологічних розробок проблем радикалізму у тих чи інших його проявах, дискурсивних системах, а також судової практики, інформаційних повідомлень у засобах масової інформації та комунікації дозволяє запропонувати таку топологію кримінального радикалізму.

\section{I. За спрямованістю агресї:}

1) екзоагресивний, що виражає спрямованість дій радикала (радикалів) на представників інших соціальних груп, утворень (органи державної влади, місцевого самоврядування, міжнародні організації, окремих посадових осіб чи суспільства в цілому);

2) ендоагресивний (аутоагресивний) - не вельми поширений тип радикалізму, який полягає у вчиненні явно аутодеструктивних практик, яким передують злочинні дії. Наприклад, захоплення заручників 3 подальшим висуненням завідомо невиконуваних вимог з подальшою провокацією правоохоронців на фізичне знищення. Такий ба- гатоходовий суїцид змістовно тяжіє фактично до жертовного акціонізму (центрованість на собі, злочинна самопожертва як соціальний жест), але лише в тих випадках, коли не поєднаний із реальним заподіянням шкоди життю і здоров'ю, майну конкретних потерпілих. В іншому випадку мова має йти про змішаний тип кримінального радикалізму.

3) змішаний радикалізм, що виявляється у специфічній комбінації аутогресивності та екзоцентрованості злочинних дій. Такою 6 діяльність терористів-смертників.

\section{II. За бормами прояву:}

1) вербальний кримінальний радикалізм, що $є$ різновидом кримінальних практик дискурсивних за своєю сутністю. Як слушно зауважує Ю. В. Орлов, навіть поверхневий аналіз природи та різновидів злочинності доводить, що існує певний іiі сегмент, що відтворюється передусім в діяльності, суспільно небезпечні результати якої настають внаслідок розгортання закономірностей інформаційної причинності. Перш за все, - це низка злочинів, які вчиняються шляхом закликів, пропаганди й інших подібних дій: публічні заклики до насильницької зміни чи повалення конституційного ладу (ч. 2 ст. 109 КК України), заклики до вчинення дій, що загрожують громадському порядку (ст. 295 КК України), пропаганда війни (ст. 436 КК України), пропаганда комуністичного та націонал-соціалістичного (нацистського) тоталітарних режимів (ст. 436-1 КК України) та ін.[1, с. 27].

Важко не погодитись із тим, що інформаційна властивість діянь також може мати суспільно небезпечний характер, соціально деструктивний потенціал, слугувати свого роду пусковим механізм, «пусковою причиною» або ж інформаційним сигналом, за яким слідуватиме негативна (небажана, небезпечна) адаптація з боку інших складових соціальної системи, а надто в контексті розуміння радикалізму як реакції дезадаптації. Її цільова природа - адаптувати середовище під запити суб’єкта такої реакції. В цьому сенсі вербальний радикалізм постає цілком природною реакцією;

2)синтетичний кримінальний радикалізм як інтеграціяфізико-енергетичної та інформаційної властивості злочинно-радикальної 


\section{Кримінальне право, кримінальний процес та криміналістика}

діяльності. Слід відмітити важливу особливість кримінального радикалізму: навіть коли він проявляється переважно у взаємодії в системі фізичної матерії, чим спричиняється безпосередня, найближча, видима шкода охоронюваним кримінальним законом суспільним відносинам, обов'язково в наявності й віддалений ефект, що зумовлюється сигнальною властивістю фізичної шкоди. Остання має певний смисл, закодований у цілі, системі цілепокладання. Ані вчинення вибухів, підпалів, пострілів, ані групового порушення громадського порядку чи організації масових заворушень, захоплення державних або громадських будівель чи споруд тощо не є самоціллю, а тому й відповідні діяння не можуть в кримінологічному аспекті розглядатися як функціонально завершені кримінальні практики. В іншому разі існує загроза наразитися на неадекватність розуміння детермінаційного процесу й факторів кримінального радикалізму, неадекватність стратегій і заходів протидії його відтворенню.

III. За ідейною (ідеологічною) основою:

1) політичний радикалізм, що є найбільш поширеним і в ідеологічній основі якого знаходяться ті чи інші концепти організації, орієнтації й використання політичної (здебільшого державної) влади. В залежності від конкретного ідеологічного змісту в такому типі кримінального радикалізму можуть бути виділений підтипи:

-правоідеологічний (архаїчний, націоналістичний). Правий радикал, орієнтуючись на грунтовні, кардинальне перетворення існуючого суспільства, переконаний, що країну необхідно повернути - якщо знадобиться, то і шляхом застосування сили - на «істинний шлях», відродити традиційні ідеали і цінності. У нього сильна прихильність до минулого поєднується ізпрагнення змінити status-quота зі справжнім новаторством в громадській діяльності[2, с. 254].

Для того, щоб не плутати цей специфічний традиціоналізм правих радикалів 3 традиціоналізмом консерваторів, деякі дослідники пропонують його називати архаїзмом. Традиціоналізм консерватизму спрямований на збереження існуючих відносин. Консерватизм з'являється тоді, коли здавна існуючий порядок починає відчувати тотальну загрозу, але ще існує і здається тим, хто його захищає, життєздатним і найкращим. Архаїки з'являється тоді, коли цей порядок повністю або майже повністю знищений і відродження його потребує виправлення нового порядку, переукладення суспільного устрою наново в ім'я ідеалу, який настільки ж неприйнятний для дійсності, як і ідеї найбільш крайніх, спрямованих у майбутне утопістів. Консерватизм прагне зміцнити існуючий лад, архаїзм - знищити його. Саме тому ці дві орієнтації непримиренні. Об'єднує їх лише те, що обидві вони звертаються до минулого як до єдиного джерела зразків, необхідних сучасному суспільству. Консерватизм послідовно антиреволюційний, архаїзм - в залежності від обставин революційний або контрреволюційний, але неодмінно радикальний[3, с. 390].

Таким чином, архаїзм - це той же правий радикалізм, але який з'являється тоді, коли соціальні групи або класи, що повстали проти status-quонамагаються зобразити свої прагнення до повернення втраченого як повернення до минулого або ж його воскресіння, для чого створюють революційнотрадиціоналістські ідеології[4, с. 14]. Через це націоналістичний та архаїчний види радикалізм нами поміщені в єдиному політичному підтипі - правий радикалізм;

-лівоідеологічний радикалізм має в своїй основі відповідні політичні ідеології «лівого» толку. Їх - доволі широкий спектр: від комунізму до фемінізму як ідеології-руху. ᄉіві радикали - послідовні антитрадиціоналісти. Їх ідеал, який був пов’язаним $з$ історичним минулим, національно-державною традицією, конструюється досить умоглядно, волюнтаристськи-раціоналістично і цілком спрямований у майбутнє. Їх суспільний ідеал - щось зовсім нове, абсолютно незвідане, що не має аналогів в історії[4, с. 14], але неодмінно пов'язане із соціальної справедливістю на засадах рівності. Остання, проте, розуміється невельми однозначно, часто взагалі без визначених критеріїв, хоч якогось філософського обгрунтування;

- анархістсъкий радикалізм, репрезентований групою ідеологічно різнорідних течій, яких, втім, об'єднує ідея спротиву центра- 
лізованій державі. Інститут держави сприймається анархістами як абсолютно функціонально надлишковий апарат концентрації влади та несправедливого примусу. Максимальна децентралізація та влада місцевих громад, побудованих за мережевим принципом - основа анархістської ідеології;

- антиглобалістський радикалізм, який по суті є ідеологічно-синтетичним, інтеграційним та націлений на протидію тенденціям глобалізації у економічному, політичному, культурному (проти мультикультуралізму, експансії агресивних культур в умовах зіткнення цивілізації) вимірі;

- «зелений» радикалізм грунтується на ідеології-русі, що набирає інтенсивності на фоні погіршення екологічного стану на планеті, може виражатися в умисному знищенні або псуванні майна, що належить експлуатаційним організаціям (нафто-, газодобувним, лісозаготівельним, рибно-промисловим тощо), груповому порушенні громадського порядку тощо.

- антикримінальний радикалізм, будучи фактично оксюмороном, тим не менш виражає рух спротиву криміналізованій владі. Поширений в окремих країнах пострадянського простору (в тому числі й України: злочини, які вчинялися під час Революції Гідності, «сміттева люстрація» тощо), Близького Сходу, Аатинської Америки, Африки.

В свою чергу, політичний радикалізм, як зазначалося в першому підрозділі цієї роботи, в залежності від спрямованості щодо об’єкту «держава» поділяється на ще два підтипи:

а) радикалізм-бунт, спрямований проти утримувачів державної влади, політичного істеблішменту чи афілійованих з ним політичних акторів - олігархів;

б) радикалізм-терор (державний радикалізм): терор, державний тероризм, злочини агресії.

Про ці типи радикалізму мова в цій роботі вже йшла. Натомість доцільно акцентувати увагу на тому, що до проміжних, сурогатних форм державного радикалізму, який тяжіє до державного тероризму, є позасудові й позавоєнні вбивствавід імені держсави та за наказом вищих посадових осіб держав. Як правило, подібні вбивства вчиняються під гаслами боротьби з міжнародним тероризмом. Так, зокрема, був позбавлений життя Усама бан Ааден, Абу Бакар аль-Багдаді, діяльність яких пов'язувалась з функціонуванням тих чи інших організацій, визнаних у США й низці інших (але не всіх, безумовно) країн терористичними. Один з останніх подібних випадків - позбавлення життя американськими військовими іранського генерала К. Сулеймані[5; 6 та ін.], що відбувалося у позасудовому порядку, у ситуації, не пов' язаній з бойовою обстановкою чи необхідною обороною. Такі дії, поза всякими сумнівами, є неправовими, а значить, враховуючи об'єкти і способи впливу, - злочиннорадикальними.

2) релігійний радикалізм, в основі якого прагнення до поширення впливу на соціальні практики того чи іншого релігійного світогляду, відповідної канонічно-догматичної чи позаканонічної системи. Найбільш вираженим цей радикалізм 6 у форматі ісламського фундаменталізму і так званого «войовничого православ'я»;

3) ксенобобний радикалізм, що може бути елементом політичного, релігійного, субкультурного чи складати окремий. В залежності від об'єкту ненависті, ворожості можливо виділити такі його підвиди:

а) антисемітизм, що виражає спрямованість проти представників єврейської національності, має давні коріння, досяг апогею у політиці нацистської Німеччини, політиці голокосту. Проте й зараз не антисемітизм як на побутовому, так і суспільно-політичному рівнях в різних країнах в тій чи іншій мірі, але виявляє свою присутність, у зв'язку з чим може розглядатися і як фонове для злочинів ненависті явище, і як безпосередньо кримінальний феномен у випадках втілення в конкретних злочинах ненависті;

б) расизм виявляє ворожу опозицію до представників іншої раси. Поширеним $\epsilon$ його (расистського радикалізму) відтворення серед осіб європеоїдної раси; спрямований проти темношкірих людей (негроїдна, ефіопська раси), індіанців, латиноамериканців (американоїдна раса), азіатів (монголоїдної раси). Відомою є діяльність організації расистського толку, яка не повністю втра- 


\section{Кримінальне право, кримінальний процес та криміналістика}

тила свої позиції, й до сьогодні зберігаючи певну популярність серед окремих верств населення південних штатів СШІА;

в) мігрантобобний радикалізм має в свої основі ненависть до мігрантів. Так, неодноразово жертвами злочинів мігрантофобних радикалів ставали українські заробітчани у Республіці Польща;

4) субкульутрний радикалізм, який відтворюється на грунті субкультурних ідеологій, a саме:

- молодіжно-субкультурний радикалізм, що представлений радикалізмомфутбольних фанатів (в частині агресивно-насильницької злочинної діяльності так званих «ультрас»радикального крила фан-руху),рух скінхедів (узагальнена назва расистських, неонацитських рухів, організацій і груп);

- кримінально-субкультурний радикалізм, що може бути поділений на два види: а) внутрішнъо-субкультурний, який проявляється всередині угрупувань засуджених та пов'язаних зі спробами змінити тюремний устрій, окремі інститути, норми, ієрархічну структуру, передбачену відповідною субкультурою. Здебільшого такий радикалізм проявляється у акціоністській та безпосередньо злочинній поведінці так званих «заперечувальників» (рос. - «отрицалово») - осіб 3 числа засуджених до позбавлення волі, які, в цілому визначаючи та сповідуючи цінності кримінальної (в тому числі й тюремної) субкультури виявляють у поведінці, комунікації принципове та показове нехтування окремими з них, демонструють зневажливе ставлення до їх носіїв, неформальних лідерів, прагнуть до зміни у балансу впливу у середовищі засуджених, перерозподілу влади авторитетів; б) зовнішньо-субкультурний, що виражає протистояння з іншими контркультурами, нормосистемами, порядками. До таких проявів кримінального радикалізму, на нашу думку, можливо віднести окремі випадки бунту засуджених, спрямованих на перерозподіл сфер неформального впливу (фактичної влади з контролем над незаконним постачанням, обігом заборонених речей, в тому числі й наркотичних засобів, налагодженням каналів надходження до режимних зон осіб, які надають оплатні сексуальні послуги тощо) в установах виконання покарань закритого типу. Імовірно, за експертними оцінками, до таких випадків можливо віднести й бунт засуджених, що стався 27.05.2019 р. у Південній виправній колонії № 51 (м. Одеса), внаслідок якого здійснило втечу 15 засуджених, вчинено підпал приміщень колонії, захоплено заручників;

5) змішаний радикалізм, в ідейній основі якого переплітаються декілька світоглядних систем, що формує своєрідні кримінально-радикальні гібриди у поєднанні ознак етнорелігійного, політико-релігійного, етнополітичного радикалізму і т.п. Наприклад, у маніфесті («2083 - Свропейська декларація незалежності»[7]), складеному сумнозвісним терористом Андресом Брейвіком, який у 2011 р. вбив у Норвегії 77 осіб та поранив ще 15, викладено комплекс ідей, що виражають ненависть до політики мультикультуралізму, мусульман, прагнення до істотного обмеження потоків мігрантів до Европи 3 країн Азї, передусім - ісламістів. Таким чином, в злочинні діяльності Брейвіка фактично відбулося поєднання релігійного, політичного та мігрантофобного (ксенофобного) типів радикалізму.

IV. За функціями в політичному процесі:

1) «революиійний рух» як крайній прояв масовогопротестного руху, спрямований на докорінну зміну суспільного ладу, його конституційних засад, маніфестацію й правове оформлення принципово нових ціннісних установок, орієнтацій загальносоціального розвитку. Втім, варто розмежовувати соціально позитивний та негативний, власне, кримінальний в цілому радикалізм;право на повстання від дій, спрямованих на насильницьку зміну чи повалення конституційного ладу. Цим питанням приділені праці В. В. Головченка, Ю. В. Орлова, С. П. Погребняка й деяких інших вчених. Разом 3 тим й досі зберігається потреба в окремому монографічному дослідження відповідного спрямування;

2) політичні репресї, що функціонально покликані забезпечити стабільність владарювання політичного істеблішменту, не допустити владний транзит, обмежити вплив політичних опонентів чи тих, хто може складати актив громадянської непокори. Політичні репресії є невід'ємним атрибутом 
недемократичних політичних режимів та загалом добре описані в історичній і кримінологічній літературі;

3) політичний терор, під яким у кримінології прийнято розуміти цілеспрямовану, системну, планомірну діяльність державних (або квазідержавних) органів щодо здійснення узаконеного масового насильства над громадянами 3 метою фізичного знищення частини населення, елімінації ідеологічного плюралізму із суспільного життя та забезпечення, таким чином, бажаних для правлячої еліти параметрів внутрішньополітичної безпеки в умовах утвердження іiі влади. Характеризуючись безпосередніми насильницькими формами реалізації, терор має стратегічну віддалену мету, яка екстраполюється не лише на сферу політичних відносин, а й на культурно-психологічну[8, c. 15]. Тож саме мета в більшій мірі і засоби - в меншій, відрізняє політичний терор від політичних репресій. Політичний терор, маючи в своїй основі фізичне знищення частини населення, завжди супроводжуюється і політичними репресіями, які неодмінно доповнюють його фізично-насильницьку природу. Проте далеко на всі практики застосування політичних репресій можуть бути охоплені політичним терором[9, с. 171];

4) кримінальний сепаратизм - радикальна, всупереч закону внутрішньодержавна відцентрова реакція представників окремих територій, що виявляє прагнення на отримання автономії чи повного (державного) суверенітету. Як свідчить історія, практично у всіх випадках саме кримінального сепаратизму присутній фактор зовнішньополітичного впливу, стимулювання сепаратного руху з метою ослаблення відповідної держави, розв'язування війни;

5) тероризм - поліфункціональний політико-кримінальний феномен, що відтворюється у феноменологічному руслі й онтологічних структурах радикалізму. Його дослідженню приділено чималу увагу, що звільняє нас від необхідності в цій роботі детально зупинятися на описі і поясненні його важливих ознак. Обмежимось лише вказівкою на те, що спектр політичний функцій тероризму - досить широкий: від політичної комунікації - до стимуляції ре сентимен- ту й синдрому Понтія Пілата (у парадигмі Д. А. Шесткоква);

6) вандалізм, що може розглядатися як тип кримінального радикалізму тільки в частині своєрідного кримінального акціонізму, як символічна дія чи боротьба із символами. Причому в буквальному сенсі - знищення символіки опозиційних наративів: знищення, руйнування або пошкодження пам'яток - об'єктів культурної спадщини, хуліганство,наруга над могилою тощо. Наприклад, неодноразова наруга над могилою Степани Бандера у м. Мюнхені (Німеччина) або ж пошкодження пам'ятника Г. К. Жукову на проспекті ім. Петра Григоренка в м. Харкові 02.06.2019 p.

\section{Висновки}

Запропоновані типи кримінального радикалізму не є вичерпними та можуть доповнюватись, набувати інтегративних рис в залежності від ситуацій, конкретного суб'єктивного змісту злочинних дій, використанням їх ефектів суб'єктами політики. Водночас виділені в цьому досліджені типи вказують на суперечливу природу радикалізму, на поєднання в ній наративної змістовної багатозначності 3 однозначністю агресивної форми діяльності, відносин контрадикції, дезінтеграції, дезадаптації на фоні утвердження групової ідентичності та єднання в опозиційності, на протиставлення приватного й публічного, їх конвергенцією та дистанційованістю на підставі кризи репрезентації. Відтак, формується досить специфічна, полімодальна, нелінійна структура феномену радикалізму, що виявляє ознаки ризоми. Виявлення ключових модусів останньої - задача для подальших досліджень.

\section{入iтepaтура}

1. Орлов Ю. В. Дискурсивнокомунікативна теорія детермінації злочинності: концептуальні засади формування. Вісник Кримінологічної асоціаџиї України. 2017. № 3 (17). C. 23-32.

2. Баталов Э. Я. Современное политическое сознание в США. М. : Наука, 1980. $412 \mathrm{c}$. 


\section{Кримінальне право, кримінальний процес та криміналістика}

3. Шацкий Е. А.Утопия и традиция. М. : Прогресс, 1990. 458 с.

4. Бороздин А. Н. Радикализм как социально-политический феномен. Вестник Академии экономической безопасности МВД России. 2015. № 6. С. 12-17.

5. За наказом Трампа: в Багдаді вбили іранського генерала Касема Сулеймані.BBC. News. Украӥна. URL: https:/www.bbc.com/ ukrainian/news-50980723 (дата звернення: 03.01.2020).

6. Bloomberg раскрыл детали ликвидации Сулеймани. КорреспонденT.net.URL: https://korrespondent.net/world/4178641B loomberg-raskryl-detaly-lykvydatsyysuleimany (дата звернення: 04.01.2020).

7. Манифест. Современность глазами радикальных утопистов / Исскуство, политика, девиация : рецензии. М. : Опустошитель, 2014.564 c.

8. Орлов Ю. В. Політикокримінологічна теорія протидії злочинності : автореф. дис. ... докт. юрид. наук : 12.00.08. X., 2016. 41 c.

9. Орлов Ю. В. Політичні репресії та терор як соціально-правові феномени : кримінологічний аспект.Вісник Кримінологічної асоичайї Украӥни. 2015. № 3 (11). С. 167-179.

\section{CRIMINAL RADICALISM: BASIC CRIMINOLOGICAL TYPES}

The article is devoted to the typology of criminal radicalism. The focus of aggression is exo-aggressive, endo-aggressive and mixed radicalism. In the form of manifestation - verbal and synthetic. Depending on the ideological basis, it is proposed to distinguish between political, religious, xenophobic, subcultural and mixed types of criminal radical- ism. Political criminal radicalism proves to be multifaceted, and can therefore be represented by such subtypes by the criterion of ideological basis: right-ideological (archaic, nationalist), left-ideological, anarchist, anti-globalist, "green", anti-criminalism. Depending on the direction of activity, the following subtypes of political criminal radicalism are distinguished: radicalism-rebellion (anti-state radicalism) and radicalism-terror (state radicalism: terror, state terrorism, crimes of aggression).

Xenophobic radicalism has the following subtypes: antisemitism, racism, and migrantophobic radicalism. Among the subtypes of subcultural radicalism are the following: 1) subcultural youth (radicalism of football fans, skinhead movement, etc.); 2) criminal-subcultural. The latter, in turn, has two more subtypes: a) intra-subcultural, which is manifested within the groups of convicts and connected with attempts to change the prison system, individual institutions, norms, hierarchical structure provided by the respective subculture; b) externally subcultural, which expresses opposition to other countercultures, normsystems, orders.

The following types of criminal radicalism are distinguished by function in the political process: "revolutionary movement", political repression, political terror, criminal separatism, terrorism (multifunctional political-criminal phenomenon), vandalism. The proposed types of criminal radicalism are not exhaustive and can be supplemented, acquired integrative features depending on the situations, the specific subjective content of criminal acts, the use of their effects by political subject, etc.

Keywords: criminal radicalism, typology, ideology, orientation, manifestation, function. 